\title{
ブドウ球菌性骨䯕炎および筋炎における 起炎菌の特異性に関する実験的研究
}

\author{
馬場孝 \\ 群馬大学医学部第一外科学教室（主任：石原恵三教授）
}

Tompson 及び Dubos（1938)1は，人の肺炎より分 離したブドウ球菌を家鬼の静脈内に接種し骨喵有炎を発 症させ，その病巣より分離した菌を用いて家鬼の静脈 内に接種すると，骨髄炎を発症しやすいと報告した。 石原ら (1955)22は，日本でしばしば観察される急性化 膿性筋炎が骨韨炎と同様に血行性に発生して，時には 多発することがあるにもかかわらず，同一患者に兩者 の合併することを見ない臨床経験にもとづき，これら 菌株にはとれぞれ異なる組織親和性があると想定し， これを支持する実験的研究を発表した．実験的ブドウ 球菌感染症は，動物種によっても違うが，一般に多 量 $\left(10^{7} \sim 10^{8} / \mathrm{m} \ell\right)$ の菌接種を必要 とする。著者は Nitromin によって，あらかじめ抗菌力を低下3.4)させ た家鬼においては，人体実験によって確められたブド ウ球菌の有效最小菌量 $\left.\left(10^{6} / m \ell\right)^{5}\right)$ 以下の菌量をもって 化膿症を起こし得ることを認めたので，この方法によ ってブドウ球菌の菌特異性を再検討した。

\section{実験材料と方法}

実験動物は生後 3〜 4 週の幼若鬼を使用した。

使用菌株は，何れも当科にて治療した患者の急性期 病巣より分離したコアグラーゼ陽性，黄色ブドウ球菌 で，骨剈道炎由来 5 株, 筋炎由来 4 株で, このほか対照之 して乳腺炎および揤由来菌株各了株を用いた。これら のファージ型は表1 の如くである.これら菌株はheart infusion agar を用い, 1 -2 カ月の間隔で継代培養 したものを用いた。

\section{1. 骨および筋肉の生菌数算定法}

正常家鬼に菌接種後の骨打よび筋内に於ける菌分布 を調べるために，骨蹃炎由来了株と筋炎由来了株，乳 腺炎および揤由来おのおの 1 株を用い $10^{8} / \mathrm{m}$ の の菌液 を家鬼体重100g あたり $0.1 \mathrm{~m}$ を耳静脈内に接種した。 生菌数算定には菌接種後 1 時間, 3 時間, 6 時間, 12時 間および48時間でそれぞれる羽を殺し，ただちに無菌 的操作により，骨では左右別々に大腿骨，脛骨および
表 1 使用菌株

\begin{tabular}{|c|c|c|}
\hline $\begin{array}{l}\text { 分離 } \\
\text { }\end{array}$ & 菌株番号 & ファージパターン \\
\hline \multirow{2}{*}{ 骨 } & $\mathrm{K}-4522$ & 71 \\
\hline & $K-4400$ & 85 \\
\hline 䪔 & $\mathrm{K}-3350$ & $3 \mathrm{~B} / 3 \mathrm{C} / 55 / 71$ \\
\hline \multirow{2}{*}{ 炎 } & $\mathrm{K}-3870$ & $80 / 81$ \\
\hline & $\mathrm{K}-3534$ & $29 / 52 \mathrm{~A}$ \\
\hline \multirow{2}{*}{ 筋 } & $K-4750$ & $80 / 81$ \\
\hline & $\mathrm{K}-3375$ & $29 / 52 \mathrm{~A}$ \\
\hline \multirow{2}{*}{ 炎 } & $\mathrm{K}-2871$ & 29 \\
\hline & $K-4001$ & $29 / 52 \mathrm{~A} / 80 / 81 / 42 \mathrm{E}$ \\
\hline \multirow{3}{*}{$\begin{array}{l}\text { 乳 } \\
\text { 腺 } \\
\text { 炎 }\end{array}$} & $\mathrm{K}-4546$ & $29 / 52 \mathrm{~A} / 79$ \\
\hline & $K-2853$ & 79 \\
\hline & $K-3853$ & 79 \\
\hline \multirow{3}{*}{ 揤 } & $\mathrm{K}--4632$ & $3 \mathrm{~B} / 3 \mathrm{C} / 55 / 71$ \\
\hline & $K-2898$ & 80 \\
\hline & $K-3723$ & 80 \\
\hline
\end{tabular}

上腕骨の上骨端部を摘出し,筋では左右の大腿四頭筋, 外腹斜筋および上腕三頭筋の一定部を摘出して重量を 計測した。これらに生理的食塩水10mとを加え10分間木 モジナイズし，1500回転，3分間遠沈後，これょり 1 $m \ell$ をとり, $7.5 \%$ 食塩加寒天培地に流し， 3 層法によ って生菌数を調へ，検体それぞれ $1 \mathrm{~g}$ あたりの菌量を 算定した。

Nitrominによる前処置，Nitrominは家禹体重100 g につき0.8mgを耳静脈内に 3 日間連続投与し，24時間 後に一定の菌量を耳静脈内に菌接種した。

2. Nitromin 投与家鬼血清の抗菌力判定法 家鬼血清のブドウ球菌に対する抗菌力をみるには， 骨㗓炎由来株 K-3870, 筋炎由来菌株 K- 4750 , 乳腺炎 由来菌株 $\mathrm{K}$ 一-4546打よび揤由来株 $\mathrm{K}$ 一-3723を用いた。 生理的食塩水にて $10^{3} / m l$ の菌液をつくり, この菌液

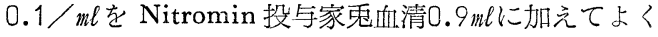
混和したのち $37^{\circ} \mathrm{C}$ の邲卵器に納め,これょり4時閠，8 
時間, 12時間, 24時間後にそれぞれ0.1mとをとり出して 普通寒天培地に流し，3層法により生菌数を算定し,菌 生存率をみた.対照として無処置家鬼血清を使用した。

3. 骨髄炎おょび筋炎の発症実験

Nitromin で前処置をした家鬼 1 群を5 羽とし, 各 菌株について実験した. 各菌株で $10^{4} / m \ell$ の菌液を作 り，家鬼体重 $100 \mathrm{~g}$ につき $0.1 \mathrm{~m} \ell$ を耳静脈内に接種し た. 発症の判定には菌接種後 3 日，5日，7日，10日 14日，21日目に全身のレントゲン撮影を行い，21日目 に殺し、レントゲン像と剖検によって骨および筋の病 巣を検索した。

\section{実 験 成 績}

\section{1.ブドウ球菌静脈内注射後の骨および筋における 菌数の変動}

（1）管璡炎由来菌 $\mathrm{K}-3870 ， \mathrm{~K}-3350 ， \mathrm{~K}-4522$ 株を 用いて骨および筋内の生菌数を調べた. 図1にみられ るょうに, 骨内では注射後 3 時間, 6 時間, 12時間お よび24時間では菌数に多少の変動はあるが，48時間に は各菌株ともに著明に增して1時間值に比べて有意の 増加（P<0.05）を示した．これに対して筋内では変 動が少なく，48時間値でも有意の増加を見ない．また 骨のうち大腿骨, 脛骨および上腕骨における菌数でも 相互間に差がなく，また筋内では大腿四頭筋，外腹斜

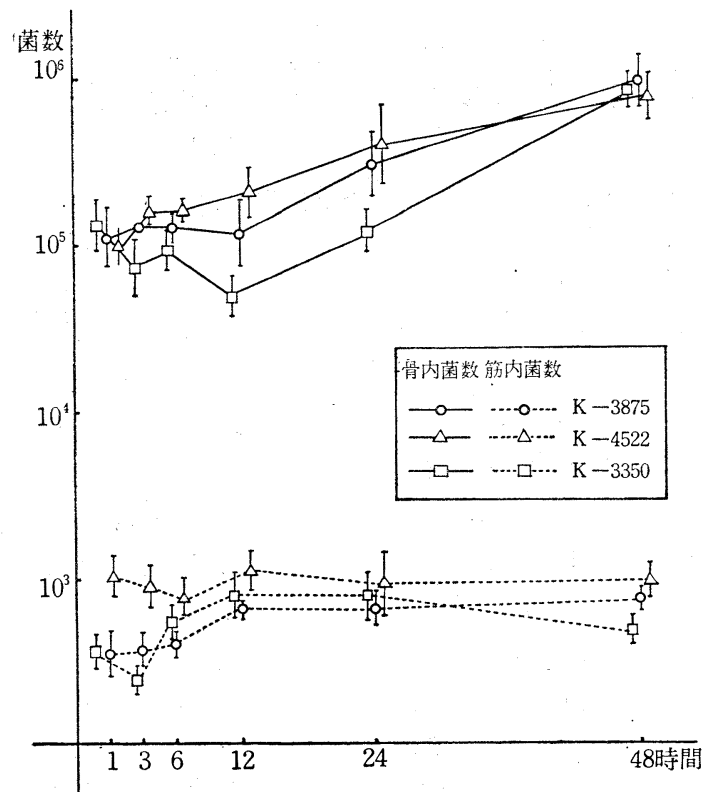

図 1. 骨髄炎由来ブドウ球菌静注後の骨および筋組織 における菌数。

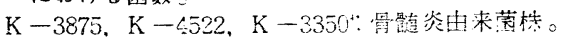

筋おょび上腕三頭筋の間にも差はみられない。

（2）筋炎由来菌K-4750，K-4001，K-3375を用以 てしらべた生菌数は, 図 2 に示すごとく, 各菌株とも 筋内では増加傾向を示し， 6 時間以後は有意に $(P<$ 0.02）増すが，骨内では減少傾向をあらわし，2株は 48時間後に有意に $(\mathrm{P}<0.01)$ 減少した。 なお大腿四 頭筋，外腹斜筋および上腕三頭筋の間では筋内菌数に 有意差がなく，また大腿骨，脛骨および上腕骨の間で も有意差がない。

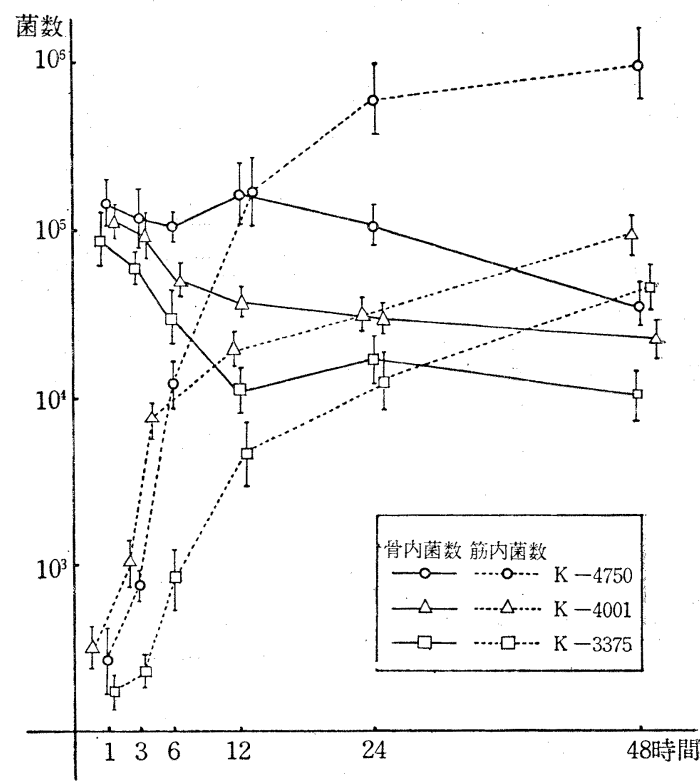

図 2. 筋炎由来ブドウ球菌静注後の骨および筋組織に おける菌数。

$\mathrm{K}-4750, \mathrm{~K}-4001, \mathrm{~K}-3375$, 筋炎由来株。

（3）乳腺炎由来菌 K-4546株および揤由来菌 K-3723 株を用いた結果は，図了に示すごとく両者とも骨内で は菌数が減少傾向を示し, 筋内ではほほほ堌減なく経過 した.

ブドウ球菌を家鬼の静脈内に注射すると，骨䯣炎由 来菌株は骨内の菌数が増加傾向をしめして48時間後に は有意に増加するが，筋では菌数の変動がみられな い.これに対して筋炎由来菌株は筋内で菌数が著明に 増加傾向をみせ， 6 時間より有意に増加する．対照の 乳腺炎または揤由来菌株は, 骨㵦炎由来菌の筋内にお ける如く，また筋炎由来菌の骨内における如き菌数の 変化傾向を示すにすぎない。

\section{Nitromin投与家鬼血清の抗菌力.}

使用した菌株は，骨髄炎由来菌 $\mathrm{K}-3870$ ，筋炎由来 菌K-4750株, 乳腺炎由来菌 K-4546お」ひび廐由来菌 K 
一-3723秼で, Nit-romin 処置家鬼皿清中における菌生 存率を調へる.103の菌量を Nitromin 処置家鬼血清

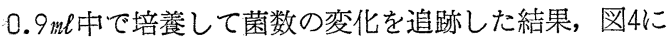
みるように，接種後 4 時間には各菌種とも Nitromin 処置血清でも，無処置血清でも菌生存率は約80\%に減 少するが，8時間には無処置血清では30\%に減少する に対し Nitromin 処置血清では僅かに減少する程度 (70\%) に止まり，12時間には無処置血清では無菌と なるにNitromi 処置血清では菌数が逆に回復して著し い差がみられた。

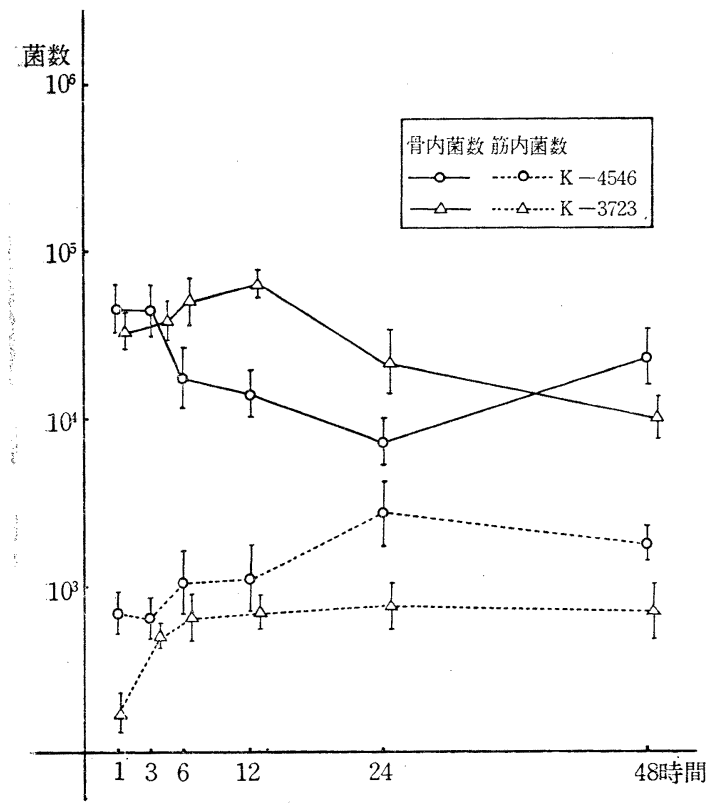

図 3、乳腺炎，獍由来ブドウ球菌静注後の骨および 筋組織における菌数。

$\mathrm{K}-4546$ 乳腺炎由来株, K-3723管由来株。

\section{3. 骨䯣炎および節炎の発生实験}

菌接種家鬼は，接種後全身状態では，不活発となり 食欲減退, 下麻, 体温の上昇 $\left(39.5^{\circ} \mathrm{C}-41.2^{\circ} \mathrm{C}\right)$ 及 び白血球数の増加 $(10,000 \sim 23,000)$ がみられ, 局所 所見では, 腫脹, 跛行がみられるものもある、レント ゲン検查で骨病栄は，7日目より骨病変が表われる が，多くは10日〜14日頃より陰影は明確になり，21日 には遊離骨影がみられる，剖検所見では，骨病盖は骨

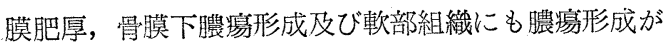
みられる。筋病巣は表面が黄白色を旺した大小の震瘍 形成を諗め, 周囲に発赤腫脹がみられた。

骨髄炎由来菌株接種群は，表 2 のごとく，70羽のう ち45羽 $(64 \%)$ に骨髄炎を発し，このうちで筋炎を合

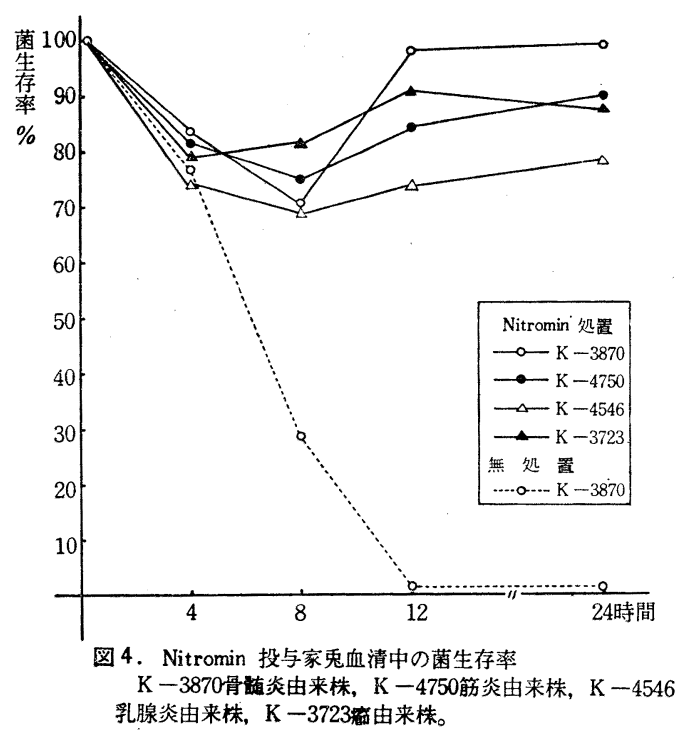

併したのが 5 羽 $(7 \%)$ あり，筋炎だけを起したもの はない，骨㖪炎のみの発生率は53～60\% (平均57\%) で各菌種間に有意差がない。骨病栄数は82か所, 大腿 骨34, 脛骨24, 肋骨12, 骨盤 6, 足根骨 5 及び椎骨 1 となり，各菌株間には著しい差がみられない. 筋炎を 合併したものは2株あって, 膿瘍は12力所に発生し, 腹筋 7 , 大腿筋 3 及び腸腰筋 2 であった。

筋炎由来菌株についてみると, 接種家鬼 43 羽のうち 28羽 $(65 \%)$ に筋炎がみられ，このうちで骨髄炎を合 併したものが 5 羽あり，骨娟道炎のみ発生したのが 1 羽 あった. 筋病栄数は75か所で腹筋25, 大腿筋23, 胸筋 15, 腸腰筋 5 , 臂筋 4 , 心筋 3 となり, 各菌株間に著 しい差がみられない.骨髄炎を合併したのは 4 株中了 株あって，大腿骨了，脛骨 2 ，肋骨 2 ，骨盤おょび足 根骨 1 となる。

乳腺炎由来菌株では接種家鬼20羽のうち6羽に筋炎, 2羽に骨賄炎，そして2羽に筋炎と骨髄炎が併発し， 筋炎発生率は40\%，骨髄炎のとれは20\%であり，3菌 株のうち 1 菌株は筋炎のみを発生した。病柴数は24で 骨では脛骨 3, 肋骨および足根骨各 1, 筋では腹筋 8 大腿筋 6 , 胸筋 4 , 腸腰筋 1 となる。

揤由来菌株では, 接種家鬼20羽のうちで6羽に筋炎, 2羽に骨㵦炎，そして了羽に骨髄炎と筋炎が併発し， 筋炎発生率は45\%，骨髄炎のそれは25\%であり，3菌 株のうちで 1 菌株は筋炎だけを発生した。病巣数は21 で，骨では肋骨 3 ，脛骨 2 ，足根骨 1 ，筋では大腿筋 


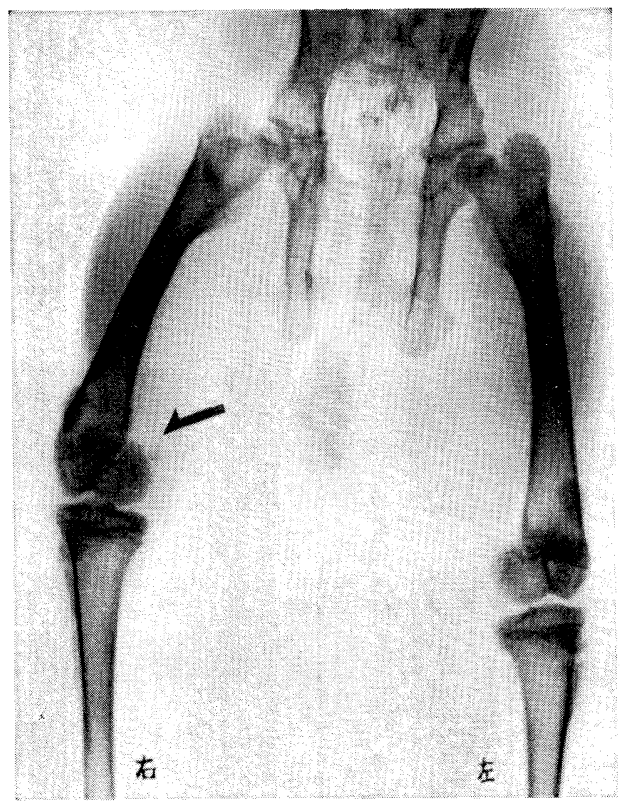

図 5. 家兔右大腿骨骨咀炎のレントゲン写真 骨髄炎由来菌（K-3870）接種後 7 日目に骨端線 に近く骨病変 (知印) 現われる。

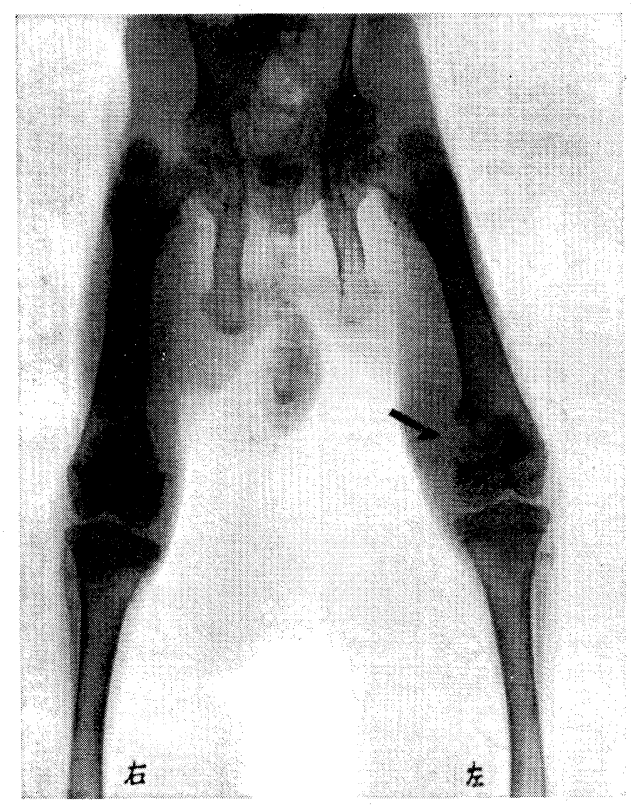

図 7. 家鬼骨髄炎のレントゲン写真 骨髄炎由来菌 $(K-3350)$ 接種後21日目に大腿骨 中間部に遊離骨影（矢印）が現われる。

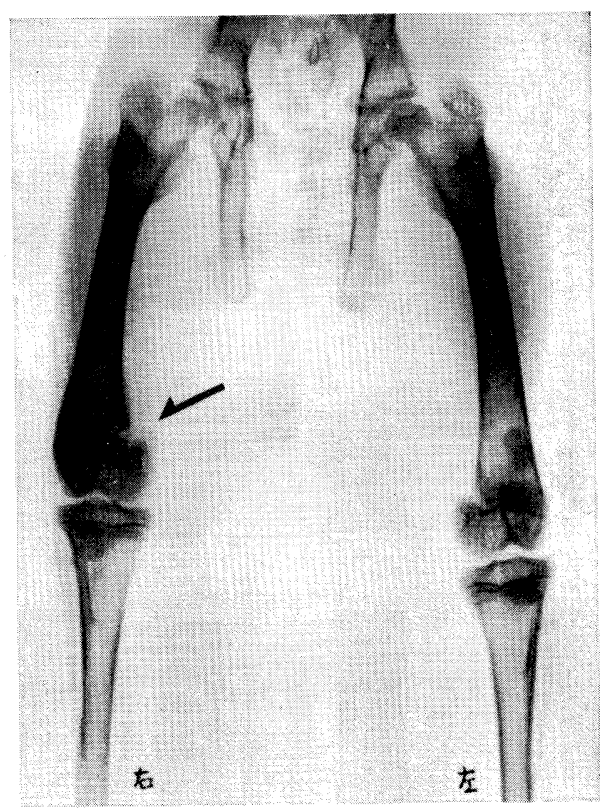

図 6. 図 5.と同じ家兔の骨髄炎, 菌接種後10日目の レントゲン写真 (骨の変化 (矢印)がいっそう明暸となる)。

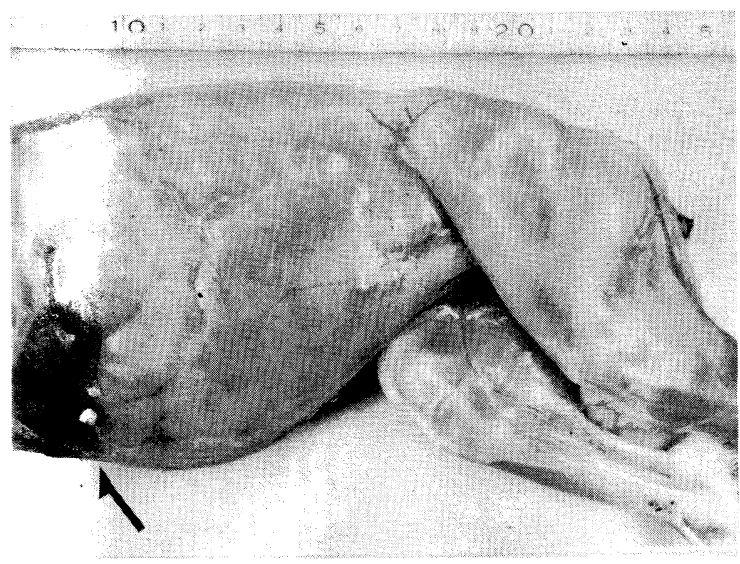

図 8. 家鬼の腹筋に発生した膿瘍の写真

筋炎由来菌 $(K-3375)$ 接種後21日目に剝皮後筋 膜を透して筋内に黄白色の膿瘍がみえ, 周囲に発赤 腫脹がある。 
表 2 各種菌株による骨髄炎および筋炎の発症

\begin{tabular}{|c|c|c|c|c|c|c|c|c|c|c|}
\hline \multirow{3}{*}{$\begin{array}{l}\text { 分 離 } \\
\text { 病 巣 }\end{array}$} & \multirow{3}{*}{$\begin{array}{l}\text { 菌 株 } \\
\text { 番 号 }\end{array}$} & \multirow{3}{*}{$\begin{array}{l}\text { 実 験 } \\
\text { 動 物 数 }\end{array}$} & \multicolumn{4}{|c|}{ 発 } & \multicolumn{2}{|l|}{ 症 } & \multicolumn{2}{|c|}{ 数 } \\
\hline & & & 骨 & 髄＼cjkstart炎 & \multicolumn{2}{|l|}{ 筋 } & \multicolumn{2}{|c|}{ 骨䯣炎筋炎合併 } & \multicolumn{2}{|c|}{ 合計 } \\
\hline & & & 動物数 & 病巣数 & 動物数 & 病集数 & 動物数 & $\begin{array}{l}\text { 骨病巣 } \\
\text { 筋病紧 }\end{array}$ & 動 物 数 & 病羑数 \\
\hline \multirow[b]{2}{*}{ 骨 } & $K-4522$ & 15 & 8 & 13 & 0 & 0 & 2 & $\begin{array}{l}5 \\
4 \\
\end{array}$ & 10 & 22 \\
\hline & $\mathrm{K}-4400$ & 5 & 3 & 7 & 0 & 0 & 1 & $\begin{array}{l}2 \\
3\end{array}$ & 4 & 12 \\
\hline \multirow{2}{*}{ 髄 } & $K-3350$ & 20 & 11 & 19 & 0 & 0 & 2 & $\begin{array}{l}2 \\
5\end{array}$ & 13 & 26 \\
\hline & $\mathrm{K}-3870$ & 10 & 6 & 13 & 0 & 0 & 0 & $\begin{array}{l}0 \\
0\end{array}$ & 6 & 13 \\
\hline 炎 & $K-3534$ & 20 & 12 & 21 & 0 & 0 & 0 & $\begin{array}{l}0 \\
0\end{array}$ & 12 & 21 \\
\hline & 合計 & 70 & 40 & 73 & 0 & 0 & 5 & $\begin{array}{r}9 \\
12\end{array}$ & 45 & 94 \\
\hline & $K-4750$ & 15 & 0 & 0 & 7 & 19 & 3 & 4 & 10 & 32 \\
\hline 筋 & $K-3375$ & 10 & 1 & 2 & 5 & 9 & 1 & $\begin{array}{r}1 \\
-3 \\
\end{array}$ & 7 & 15 \\
\hline & $\mathrm{K}-2871$ & 9 & 0 & 0 & 6 & 17 & 1 & $\frac{2}{4}$ & 7 & 23 \\
\hline 炎 & $K-4001$ & 9 & 0 & 0 & 5 & 14 & 0 & $\begin{array}{l}0 \\
0\end{array}$ & 5 & 14 \\
\hline & 合計 & 43 & 1 & 2 & 23 & 59 & 5 & $\begin{array}{r}6 \\
16\end{array}$ & 29 & 84 \\
\hline 乳 & $\mathrm{K}-4546$ & 10 & 1 & 2 & 3 & 7 & 1 & $\begin{array}{l}1 \\
2 \\
\end{array}$ & 5 & 12 \\
\hline 腺 & $K--2853$ & 5 & 1 & 1 & 1 & 2 & 1 & $\begin{array}{l}\frac{2}{1} \\
2\end{array}$ & 3 & 6 \\
\hline 炎 & $K-3853$ & 5 & 0 & 0 & 2 & 5 & 0 & 0 & 2 & 5 \\
\hline 炎 & 合計 & 20 & 2 & 3 & 6 & 15 & 2 & $\begin{array}{l}2 \\
4\end{array}$ & 10 & 24 \\
\hline & $\mathrm{K}-4632$ & 10 & 1 & 2 & 3 & 4 & 2 & $\frac{1}{2}$ & 6 & 9 \\
\hline 廐 & $K-2898$ & 5 & 1 & 2 & 1 & 2 & 1 & $\begin{array}{l}1 \\
3\end{array}$ & 3 & 8 \\
\hline & $\mathrm{K}-3723$ & 5 & 0 & 0 & 2 & 4 & 0 & $\begin{array}{l}0 \\
0\end{array}$ & 2 & 4 \\
\hline & 合＼cjkstart記 & 20 & 2 & 4 & 6 & 10 & 3 & $\begin{array}{l}2 \\
5 \\
\end{array}$ & 11 & 21 \\
\hline
\end{tabular}

9 , 腸腰筋 5 , 腹筋 1 となる. 乳腺炎及び筋炎に由来 する菌では大腿骨に病変が出なかった点が注目され る。以上の結果より乳腺炎おょび揤の起炎菌は, とも に骨䯣炎よりも筋炎をょり多く起すが, 筋炎の発生率 は筋炎由来菌上り少なく, 骨髄炎の発生率は骨髅炎由 来菌よりもはるかに少なく, 有意差 $(\mathrm{P}<0.001)$ があ る。

\section{考按}

化膿性骨䯣炎は, 古く Lexer $\left.{ }^{6}\right)$ 以来, ブドウ球菌が 長管骨中間部の小血管に細菌性栓塞をきたし発症する
ものとされ，その成因には発育期の南管状態のほか に, 局所の外傷, うっ (ffl. ${ }^{7)}$, アスコルビン酸の欠乏 ${ }^{8)}$ など, 宿主がわの原因が追究されている。骨髄炎と筋 炎とが同じくブドウ球菌の向行感染で起るとする場合 に，この両者が同一患者で併発しない点でブドウ球菌 の単一性については疑問がもたれる。教室のさきの報 告によると, 骨髄炎および筋炎より分離した菌株を幼 若家鬼の骨髄内に接種すると, 前者は長管骨に, 後者 は骨格筋に膿瘍を作る傾向がはなはだ著明である。今 回の実験では従来使用されている幼若家匛に対し, で きるだけ少ない菌量のブドウ球菌を用いて発症させる 
ために, Nitromin の前処置法を採用した。その結果 $10^{4} / m \ell / 100 \mathrm{~g}$ の菌量を家鬼耳静脈队に接種して, 羅患 率は60\%近くに達した。骨葡炎由来菌株の接種では， 骨䯣炎は70羽中の 45 羽 $(64 \%)$ に発症し，このうち 5 羽は筋炎を併発したが，筋炎だけの発生はなかった。 発生部位は大腿骨が最も多く, 脛骨, 肋骨, 骨盤, 足 根骨の順である。つぎに筋炎由来菌株では，43羽中の 28羽(65\%)に筋炎が発生し，このうち骨髄炎だけの発 生が1羽ある。これに対し, 乳腺炎打よび仯由来株で は, 40羽中12羽 (30\%) で筋炎が, 4羽 (10\%) で骨

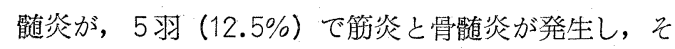
の発生部位は筋では大腿筋, 腹筋, 胸筋, 腸腰筋で, 骨では脛骨, 肋骨, 足根骨に見られたが, 大腿骨には 見られなかった。なおブドウ球菌の静脈内注射後に骨 および笳組織内における生菌数をみても, 骨酭炎由来 菌は24一-48時間で骨内では増加傾向を示し, 筋内では この傾向が見られないが，筋炎由来菌は筋内で 6 時間 以後有意に堌し, 骨内ではかえって減少傾向を示し, また乳腺炎抢よび癖由来菌は24時間に骨内ではやや減 少し筋内ではやや増したが著明な増娍はみられない。 以上の所見から化膿性骨鹃炎炎上び筋炎の起炎菌とな るブドウ球菌は相互に，また乳腺炎打よび揤の病原ブ ドウ球菌とも異なる病因的性格をとなえていることが うかがわれる。

$$
\text { 総括 }
$$

正常幼若家鬼を用いて, 化膿性骨㵦炎, 筋炎, 乳腺 炎および廐から分離したブドウ球菌を静脈内注射し， 骨および筋組織内の生菌数を算定してみると, 骨㖪炎 由来菌は筋組織内ではあまり変化がないが, 骨組織内 では48時間後に増加傾向がみられた。これに対し, 筋 炎由来菌は筋組織内では 6 時間後より有意に増加した が骨組織内では減少傾向を示した。たほう, 乳腺炎お よび㢃由来菌は骨組織と筋組織内に有意な変化をきた さなかった。
Nitromin 前処置幼若家鬼にブドウ球菌を静注して 骨髄炎打よび筋炎の発症状態をみると, 骨㵦炎由来菌 では70羽中45羽 (64\%) に骨髄炎が発生し，このうち 5 羽に筋炎を併発したが筋炎だけの発生はない。たほ う筋炎由来菌では筋炎が43羽中の28羽 $(65 \%)$ に発生 しこのうち5羽に骨髄炎が併発し，ほかの1羽に骨髄 炎を見た。これに対し，乳腺炎㧍よび揤由来菌では40 羽のうち12羽 (30\%) に筋炎が発生し，4羽 (10\%) に骨䀎道炎，5羽 $(12.5 \%)$ に筋炎之骨䯣炎の併発が 女 られた。骨檤炎は大腿骨が最も多く, 脛骨, 肋骨, 骨 盤, 足根骨, 椎骨の順で, 筋炎は腹筋と大腿筋が最も 多く胸筋, 腸腰笳, 留筋, 心筋の順であり, 菌株別に よる差は明らかでない。

化膿性骨髄炎および笳炎の起炎菌となるブドウ球菌 は相互に，また乳腺炎および揤由来菌とも異なった病 因的の性格をそなえていると推論される。

閐筹するに当り, 御指道と御校閲を㫜った恩師石原恵三教 授をはじめ田島昭三助教授，教空員各位に深く感謝いたしま す.

\section{文献}

1) Thompson, R.H.\&R. J. Dubos: J.Exp.Med., $68: 191,1938$.

2) 石原, 原田, 神部, 若尾 : 日本外科誌, $56: 574$, 1955.

3) Derby, B.M.\& D.ERogers: J.Exp.Med., 113 : 1053, 1961

4 ) 森谷: 日本医学放射線学会誌, $15: 610,1955$.

$5)$ Elek, S.D.\&P.E. Conen:Brit. J. Exp. Path.. $38: 573,1957$.

6) Lexer, E.:Arch.Klin.Chir., $48: 181,1894$.

7) Rosenbach, F. J. : Mscht. Unfallheilk., 46 : 598, 1939.

8) Takahashi, R. : Arch. klin. Chir., $181: 103$, 1934. 


\section{EXPERIMENTAL STUDIES ON THE SPECIALITY OF STAPHYLOCOCGAL STRAINS GAUSATIVE PURULENT OSTEOMYELITIS AND MYOSITIS TAKASHI BABA \\ Department of Surgery I, Gunma University, School of Medicine, Maebashi, Japan. \\ (Director : prof. Keizo Ishihara)}

Animal experiments have shown evidences in sepport of a hypothesis that some special strains of staphylococci are responsible for the development of staphylococcal infection of various tissues.

Firstly, of intravenously inoculated staphlococci obtained from surgical patients of purulent osteomyelitis, myositis, mastitis and furuncle, osteomyelitic staphylococci were recovered more numerously from bone tissues of young rabbits after 48 hours than those of other sources, and myositic staphylococci were similarly recovored from muscles after 6 hours. In contrast, other strains showed no special findings.

Secondly, young rabbits rendered susceptible to infection by pretreatment of Nitromine were intravenously injected with a small dose of staphylococci $\left(10^{4} / \mathrm{ml}\right)$ of origins mentioned above.

The results have shown osteomyelitic and myositic staphylococci caused respectively osteomyelitis and myositis more frequently $(64-65 \%)$ than other cocci. 